\title{
Enhance Academic Study in Vocational Education in China
}

\author{
Ling Sun (Corresponding author) \\ School of Economic and Trade, Chongqing Educational College \\ 9 Xue Fu Street, Chongqing 400067, China \\ Tel: 86-23-6265-8151Ｅ-mail: mission2009@126.com
}

\begin{abstract}
The increase in international trade and the information technology boom led us to begin to face the previously unthinkable of academic shortage towards vocational education. The main objective of this paper is to present the problem and find ways to solve it. The main finding included lack of investment from society and high degree involvement of government, the curricula is without of academic flexibility, students are sorted into different school types largely on the basis of their entering exam score, shortage of high-quality teachers and instructors. Thus this paper puts four ways to tackle the problem: decrease the involvement of government; setting hybrid curricula and providing technical research project; providing attractive option that the possibility to study further in university for vocational school graduates; emphasizing general and academic knowledge over industry and vocational skills by aligning academic institutions and firms.
\end{abstract}

Keywords: Academic study, Government, Education budget, University

\section{Introduction}

Expanding access to vocational education can be an attractive option for people in developing countries seeking to improve labor market outcomes. A large number of graduates from vocational schools fueled China's manufacturing export machine as skilled workers. However, it has become obviously that with increasing international labor market demands that heavily rely on commercial and technology and therefore, require academic flexibility from the job applicants. Shifting demands of modern life require academic flexibility to adjust to the changes constantly going on in the labor market. Therefore, vocational education is perceived as a disadvantage for a job applicant due to the limited skills and knowledge that the vocational schooling has provided for him.

Thelen pointed out in vocational education new technologies and new production requirements demand on going upgrading of training, mostly in the direction of more general skills and more theoretical training. Lauglo argued that vocational education was least practical because students frequently migrated to cities for better career opportunities that often made their vocational education irrelevant for the job aspirations that they pursued. They were restricted in their job choice to the limited skills and knowledge that they had acquired at vocational schools. Due to lack of academic education, they could not fulfill the requirement of society development. The current globalization also has spurred major debates on vocational education in many countries such as US, Italy and Germany. In two, the US and Italy, major reforms aimed at strengthening general, academic skills had been enacted. In Germany, government tried to establish national standards to improve school and students performance.

Our paper makes four main findings. First, students are primarily sorted into school type based on their entering test scores. Second, budget of vocational education is small amount. The involvement of local government is at high level to vocational schools. Third, vocational schools remained major skill-oriented instruction, students could not get the preparatory path towards higher education. Finally, there are not enough high quality instructors in vocational schools.

There are four main contributions to the literature. The first main contribution is independence from government involvement. The second main contribution is providing hybrid curricula with more academic lessons and technical research project. The third main contribution is supporting the way to future university study. The final main contribution is aligning academic institutions and firms.

We organize the rest of this paper as follows. The next section provides background of the China vocational education system. Section 3 investigates the findings and presents the ways to solve problem. The final section gives the summary.

\section{Background of vocational education in China}

In China, general high schools prepare students specifically for the university education. Vocational and 
technical high schools (henceforth, referred to as vocational schools) provide vocational training with the main objective of imparting specific marketable skills. Their graduates are eligible to participate in the college entrance examinations but not directly to university. Traditionally, only graduates of the elite gymnasium have been admitted to university study. In China students are sorted into different school types largely on the basis of their entering exam score. General high schools attract the highest scoring and talent students, while vocational schools serve the lowest-scoring students.

Figure 1 shows the investment share of total education budget with general high school and vocational school. Vocational education is considered to be more expensive than general education [2].But since 1993 vocational education budget began to be lower than that of general education. In 2004, vocational education budget was only $6.15 \%$ of the total amount and $4 \%$ lower than that of general education. Lack of fund can not sustain a high quality teacher team especially with high academic level.

Insert Figure 1 Here

Figure 2 points out the high degree involvement of government. Up till now there are 2590 private vocational schools. They make only $4 \%$ share of the total number of vocational schools. The World Bank [6] emphasized the importance of private provisions of vocational education or training due to high costs of provision and the abundance of private providers. The situation in China is contrary.

Insert Figure 2 Here

\section{Analysis and Solution}

\subsection{Further Study for Vocational Education Graduates}

According to the background information, general education which can support further academic study in university is more attractive to Chinese students. Traditionally talent students go to study in university. They can get high score and have the chance to entering general high schools. As the vocational school can not provide the way to university directly, its route seems a dead end. If students in vocational schools have the possibility to go for further study in university, it will not only attract more talent students, but also the vocational schools students will pay more attention to academic study. Thus even if the graduates could not pass the entering exam to university and turn to find jobs, the skill-oriented course with academic education would enable them to land in various jobs.

\subsection{Hybrid Curricula and Technical Research Project}

Vocational schools provide various courses to students, such as business, computer, fashion design, automotive, travel and welding. However, one factor that most individuals would like to enroll in a certain type of course is its demand status. Both the vocational schools and students ignore that the academic flexibility for the graduates would lead to fit their knowledge and skills to the changing demands of labor market. We suggest the possibility of hybrid curricula and research projects. Vocational school curriculum still can remain mainly "academic" or general. The subjects included mathematics, English, physics and history. Students could take such subjects (some 4-5 hours a week) and yet remain on the preparatory path towards higher education. Research projects can play an important role in vocational education, technique invention and innovation is also a part of the responsibility of vocational schools.

\subsection{Less involvement of Government}

The degree of independence of vocational schools from governmental control is another important issue that determines the efficient implementation of vocational education and its beneficial implementation in a country. In china most of vocational schools are public and have strong relationship with government. The government support vocational education less budget since 2001 and it has great impact on the development of vocational schools. It also can not respond to the market change timely and efficiently especially facing high requirement in the fast change of globalization trend. The vocational education should be moving towards more skill and technique oriented instruction. It would be much more efficient to entrust vocational educational and training programs to private providers who would keep track of labor market changes and demands more effectively and would provide more relevant, up-to-date, more academic trainings at their expense, thus freeing significant portion of public money and lessen the impact from decrease of government budget.

\subsection{Alliance with Academic Institutions and Firms}

Vocational schools are suffering an acute shortage of high-quality teachers especially facing the requirement of academic education. As vocational education budget is not enough, teachers' income is at a low level comparing to that of general high school teachers. Another reason is that vocational education is considered as a 
second-class education that makes it difficult to employ high quality teachers. Independence of vocational schools from governmental control can partially solve this problem due to more investment from private fund. We suggest that emphasizing general and academic knowledge over industry and vocational skills by aligning academic institutions and firms is way to bring high quality instructors. Professors and teachers from universities and generally high schools can greatly support academic teaching task in vocational schools. This is also a way to get full use of high quality teaching resource in China. Local business leaders can be volunteers in schools, thus the linkages with enterprises and universities, incentives to attract and retain qualified instructors and students and forms good feedback systems.

\section{Conclusion}

Following noteworthy conclusions can be drawn from the overall discussions in the paper. Several significant reasons of lack of academic education in vocational schools could be summarized as follows: shortage of investment from society and high degree involvement of government, the curricula is without of academic flexibility, students are sorted into different school types largely on the basis of their entering exam score and vocational schools are treat as second-class schools. Vocational schools are in shortage of high-quality teachers and instructors.

To tackle the above shortcoming several suggestions have been made. Decrease the involvement of government; setting hybrid curricula and providing technical research project; providing attractive option that the possibility to study further in university for vocational school graduates; emphasizing general and academic knowledge over industry and vocational skills by aligning academic institutions and firms.

\section{Acknowledgements}

Mission thanks to my tutor, the Professor Zeng guoping. Thanks to my husband, Wang sen, without your comprehension and help, I can not accomplish this paper. Thanks to my family members and my friends, without the support from you, I can not finish this paper. Thanks to the editor, without your work, I can not submit this paper.

\section{References}

K.A.Telen. (2004). Beyond continuity: Institutional change in advanced political economies. Oxford University Press.

Oketch.M, Book review of Vocationalisation of Secondary Education Revisited. Technical and Vocational Education and Training. Issues, Concerns and Prospects. 2005, pp. 138-156.

Lauglo,J. (2008). Revisiting the Vocational School Fallacy. Annual conference of the Comparative and International Education Society. 3 (4): 13-26.

Foster, P. (1965). The vocational school fallacy in development planning. In C. Education and economic development.2(4)142-166.

Sara Jane McCaffrey. (2009). The Politics of Education and Training Reform in Advanced. Industrial Economics. 2(3):97- 128

World Bank. (1991). Vocational and technical education and training: A World Bank policy paper. The world bank.

Min, W. \& Tsang, M.C. (1990). Vocational Education and Productivity: A Case Study of the Beijing General Auto Industry Company, Economics of Education Review, 9, pp. 351-364

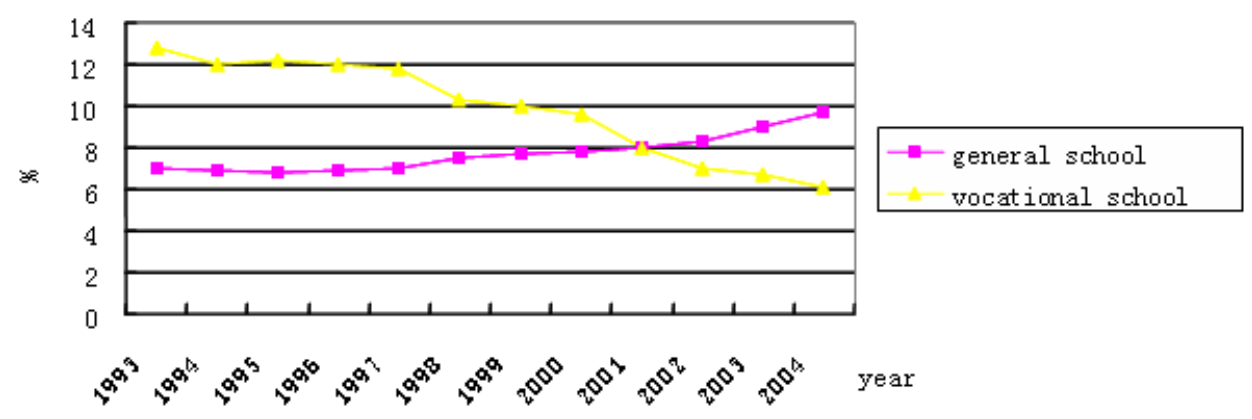

Figure 1. budget of vocational and general education in total education budget share 


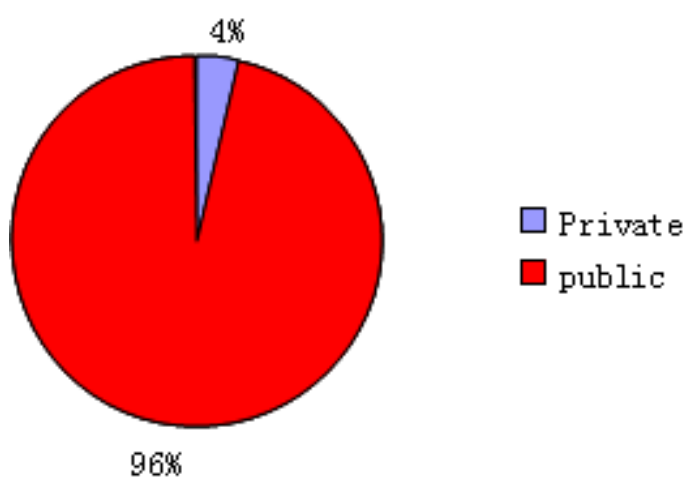

Figure 2. private and public vocational schools 